\title{
Global meliponiculture: challenges and opportunities
}

\author{
Marilda CORTOPASSI-LAURINO ${ }^{\mathrm{a}}$, Vera Lucia IMPERATRIZ-FONSECA ${ }^{\mathrm{b}}$, \\ David Ward RoubiK ${ }^{\mathrm{c}}$, Anne Dollin ${ }^{\mathrm{d}}$, Tim HEARD ${ }^{\mathrm{e}}$, Ingrid AGUILAR ${ }^{\mathrm{f}}$, Giorgio C. \\ VENTURIERI $^{\mathrm{g}}$, Connal EARDLEY ${ }^{\mathrm{h}}$, Paulo NOGUEIRA-NETO ${ }^{\mathrm{a}}$ \\ ${ }^{a}$ Ecology Dept., Biosciences Institute, S. Paulo University, Brazil

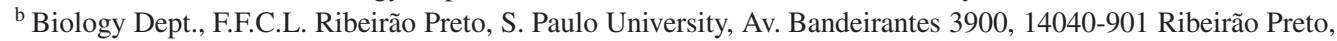 \\ Brazil \\ c Smithsonian Tropical Research Institute, Balboa, Republic of Panama \\ d Australian Native Bee Research Centre, PO Box 74, North Richmond New South Wales 2754, Australia \\ ${ }^{\mathrm{e}}$ CSIRO Entomology, 120 Meiers Rd, Indooroopilly Queensland 4068, Australia \\ ${ }^{\mathrm{f}}$ CINAT Centro de Investigaciones Apícolas Tropicales, Universidad Nacional, 475-3000 Heredia, Costa Rica \\ ${ }^{g}$ EMBRAPA Amazônia Oriental, PO Box 48, Belém-PA, CEP 66.017-970, Brazil \\ ${ }^{\mathrm{h}}$ ARC Plant Protection Research Institute, Private BagX134, Queenswood, 0121, South Africa
}

Received 19 January 2006 - Accepted 15 February 2006

\begin{abstract}
Stingless bees are social bees that live in tropical and subtropical areas of the world. All species produce honey, which has been appreciated by humans since ancient times. Here, the general panorama of meliponiculture is presented. Deforestation and poor management are the main problems faced by this incipient industry. For a profitable meliponiculture, much more biological information is needed, as well as field studies in natural conditions. In the near future, we suggest that the successful use of these pollinators will promote the development of new breeding techniques and commercialization possibilities, which must be designed to be sustainable.
\end{abstract}

meliponiculture / stingless bees / breeding / honey / wax / pollinators / Apidae / Meliponini

\section{INTRODUCTION}

Stingless bees together with honeybees are eusocial insects. Stingless bees have been known for their honey and pollen production, but nowadays their role as the providers of ecosystem services is also recognized. Today, over 600 species in 56 named genera live in tropical and subtropical areas of the world; 400 known species exist in the Neotropical region, and it is estimated that there are more than 100 to be described (Camargo, pers. comm.). The stingless bees reach $32^{\circ} \mathrm{S}$ to $38^{\circ} \mathrm{S}$ in South America and Australia, respectively, $28^{\circ} \mathrm{S}$ in

Corresponding author: M. Cortopassi-Laurino, mclaurin@usp.br

Present address: Biological Science Centre, Santa Catarina Federal University, 88040-900, Florinopolis SC, Brazil.
Africa, and a little beyond the tropic of Cancer in the Northern hemisphere.

Stingless bee beekeeping is known as meliponiculture. This activity, generally undertaken by traditional communities, has local characteristics according to regional and traditional knowledge. Honey and a waxy material (the cerumen of stingless bee nests is not pure wax, but a wax/plant resin mixture) were the traditional products. Resin is also occasionally an important income source for the stingless bee beekeeper, as well as the renting of colonies for pollination service.

In this paper, the regional status of meliponiculture worldwide is considered. The use of stingless bees as crop pollinators has opened a new economic possibility for meliponiculture. Large-scale rearing of stingless bees is a current challenge as it must be aligned with sustainable development. 


\section{ORIGINS OF MELIPONICULTURE}

Although diverse indigenous peoples lived in Mexico when the Spanish conquerors arrived in sixteenth century, the ancient Maya people held stingless bees in high regard and considered them an integral part of social and religious life. At that time, stingless bees provided a vital small-scale economy, due to their honey (used as medicine, as sweetener and for mead), their waxes, and resins. The cultural importance of a single central species, called Xunan-Kab (Melipona beecheii), was recorded in documents written with ideograms by the Maya, recorded in their codices. Only three of these codices have survived and one, the Tro Codex, contains most data on bees and their meaning to society.

The honey produced by Xunan-Kab was considered sacred by the Maya and was also traded. Lopes de Gomara (1552) wrote that stingless bee honey occurred in different colors, flavors, and fluidity, and indicated that it was an important medicinal product. Honey was also used to pay taxes to the Aztecs, and Inca (Cobo, 1653; Roubik, 2000). In Mexico, there was a god of honey, while honey and cerumen of $M$. beecheii were used in sacred ceremonies. Even today, in catholic churches in Puebla, Mexico, it is possible to see wax objects offered to God. Besides the modern cultural changes, the stingless bees, especially the Xunan-Kab, are among the few native organisms that possess a widely acknowledged status as a cultural, ecological and economic icon (De Jong, 2001; Villanueva et al., 2005b). However, beekeeping with stingless bees has sharply declined in the last half century. Villanueva et al. (2005a) made the first census of meliponiculture in Mayan communities in Yucatan, and verified that this activity is almost extinct (90\% of colonies have been lost in the last 25 years).

In Brazil, stingless bees play an important role in the ethnobiology of the Kayapó (Posey and Camargo, 1985; Camargo and Posey, 1990). They named and classified 34 species of stingless bees, of which 9 were considered managed or semi-domesticated. Resin and cerumen were used in their artifacts and as medicine. The natural world model of the
Kayapó universe was taken from social insects, including stingless bees, ants and wasps. In their religious ceremonies, meliponine wax or cerumen was used. Camargo and Posey (1990) mention that some Kayapó individuals knew many details of bee behavior, distribution, nest types and their respective ecological zones. The bee specialists in Gorotire were all shamans: they looked for bee nests during the night (they were not afraid of spirits), and could find them by the noise from nest ventilation, which they recognized for each bee species (see also Kajobe and Roubik, 2006). They also could follow the odor that bees used to mark nesting sites. The person that found the nest became its owner and could exploit it, using several techniques according to the species. Indigenous people use smoke for managing aggressive bees, such as Oxytrigona, and also use a common toxic liana (Tanaecium nocturnum, Bignoniaceae) to manage the bees, which causes bees to sleep after 1 or 2 minutes. All knowledge on bees was passed orally through generations. The traditional way of finding nests by the noise made by worker bees during nest ventilation is still a method used by many native people from different communities in Eastern Amazon. These collectors usually mark the trees with a nest inside during the night. Later, during the day, the nests are collected.

The Kayapó exploit stingless bee nests (Melipona seminigra pernigra, M. melanoventer, M. rufiventris flavolineata, Scaptotrigona nigrohirta, $S$. polysticta, among others) during several consecutive years. When they open natural nests to collect food, some brood, pollen and honey is left for the spirit " $\mathrm{Bep}$ kororoti" and this allows recovery of the colony. Some species like Tetragonisca angustula, Trigona cilipes and $T$. dallatorreana are brought into houses in baskets made with banana leaves, and thus are under semidomestication. The Kayapó seem to be aware of the role of stingless bees as crop pollinators (Slaa et al., 2006); they tend to plant bee plants near their crops to attract the bees.

In Africa, Byarugaba (2004) discussed the Abayandas pygmy indigenous knowledge on stingless bees in the Bwindi forest reserve, Uganda. He explained that Bwindi is a forest 


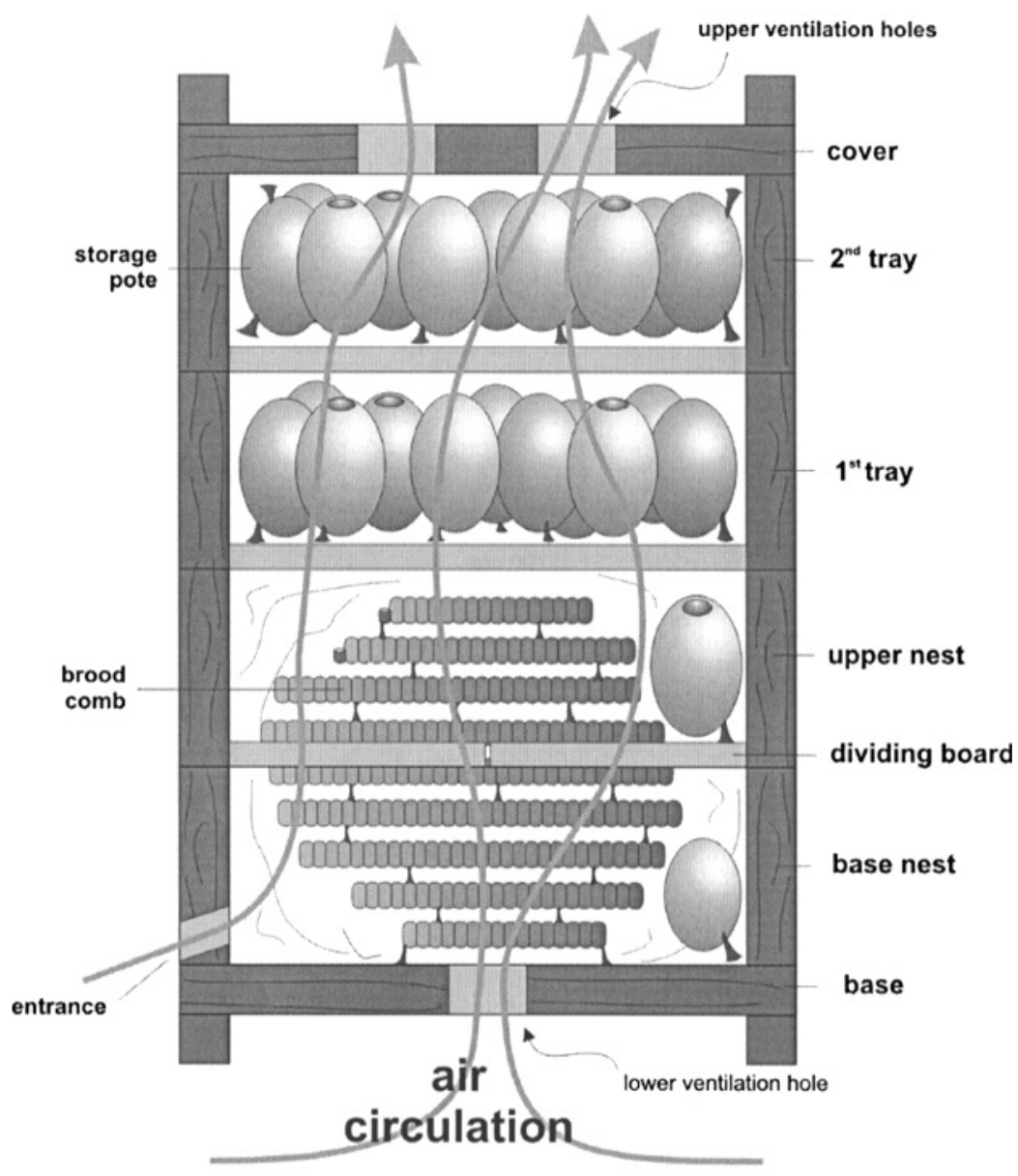

Figure 1. Vertical hive with special ventilation system for stingless bees of tropical areas (from Giorgio C. Venturieri in www.cpatu.embrapa.br/meliponicultura.htm).

island, where different types of forests merge, and the diversity of species in many groups is higher than in other parts, yet only six species of stingless bees are found there. Batwa pygmies, Abayanda, Bakiga and Bafumbira people use the honey of Meliponula ferruginea and other bees for medicine, e.g. to alleviate constipation.

\section{FROM TREE HOLLOWS TO STANDARD HIVES}

The first step in meliponiculture was the maintenance of nests around a shelter or home in the original section of a tree trunk or branch.
Stingless bees nest mainly in tree hollows. For such species, it is easier to move and maintain a nest in artificial wooden hives. Subterranean nests, compared to aerial nests, are difficult to maintain in hives. Considering the variety of bee species, a large array of boxes, differing in style and size, have been built and tested. In Brazil, horizontal hives are much more common than vertical ones. Some beekeepers believe that the vertical boxes supply the bees with the same conditions they have in the logs. Vertical hives with a special ventilation system have been built in hot, tropical areas (Fig. 1). Rational hives made of wood, with a central place for brood and surrounding area for honey or pollen pots, as suggested by Nogueira-Neto 


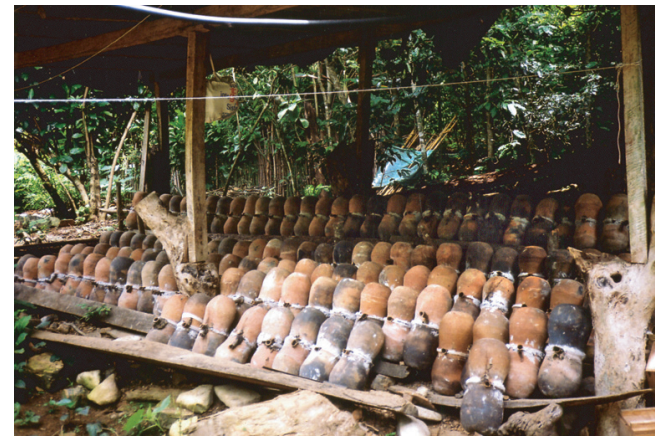

Figure 2. Clay Hives of Scaptotrigona mexicana used by native people in Puebla, Mexico (photo by Cortopassi-Laurino).

(1997), have been modified by beekeepers. Modifications have also been made in hive volume, adapting them for the size of each rearing species. Ceramic clay hives (Fig. 2) are still used by indigenous people in Mexico as well as by some traditional populations in Brazil (Castro, 2005). Mud is often used to close the logs and rudimentary hives in the field, after management, to prevent enemies from entering the nest (primarily phorid flies and ants).

In Northeast Brazil, where meliponiculture is relatively developed, beekeepers try to use the same wood for constructing hives as used by the nesting wild colonies, for instance Commiphora leptophloeos (Burseraceae) for Melipona subnitida (Martins et al., 2004).

\section{ESTABLISHING A MELIPONARY}

Stingless bees live in colonies that reproduce by a process called swarming, but this is not the same process employed by honey bees (Nogueira-Neto, 1997). Colonies are longlived; there are reports of a nest remaining active more than 50 years in a protected log hive, but is not known how many swarms they issue during their lifetime, nor how long queens live, but the expected time required for colony reproduction greatly exceeds queen longevity. One possible way to obtain nests for establishing new meliponaries is to capture natural swarms by offering suitable artificial nests. Inoue et al. (1993) found that with the introduction of artificial nest sites in orchards the

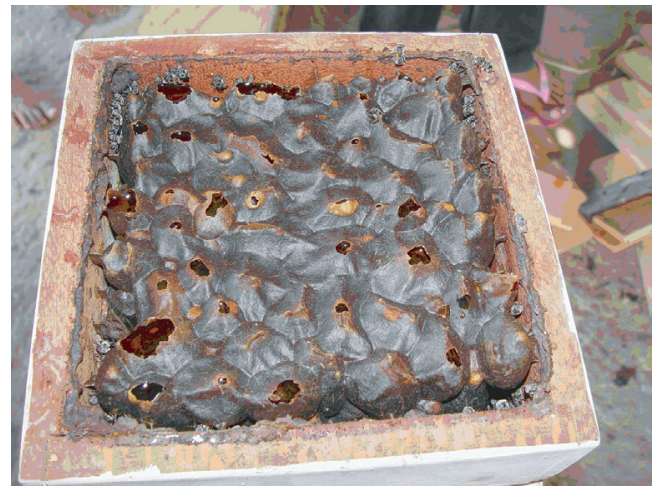

Figure 3. Tray of honey pots from Melipona compressipes fasciculata ready to be collect (photo by G.C. Venturieri).

colony density of Trigona minangkabau increased by 2-5 times. In southern Brazil some beekeepers use empty bottles, with an entrance made with cerumen, to attract stingless bee swarms; such artificial nest sites are attractive to Tetragonisca angustula. Empty hollow logs can be used as a hive, as Ratnieks and Hart (2001) described for a Maya Indian stingless bee beekeeping:

"To divide a colony, Benancio takes some combs of emerging brood and honey from one hive and places it in an empty log hive which has been smeared inside with honey. The newly emerged bees then go to work and one of the newly-emerged queens takes over. During the honey harvest he noted colonies with brood suitable for making the divisions. Colonies can also be obtained from the wild by cutting down the tree in which they are living, but it is rarely done"

Other beekeepers prefer to use special hives for keeping their bees. According to the species harvested and region, hives have different models and sizes. Silva et al. (2004) verified that colonies established in standard hives produce more honey than in "caboclo" or rustic hives, and thus teach small farmers in the Amazon how to construct standard hives for their local species. The hives facilitate nest multiplication, honey collection, colony thermoregulation, and other necessities for meliponiculture (Fig. 3). 


\section{LOGGING AND STINGLESS BEES}

Stingless bee nests in nature are in danger of depletion by logging practices. In Malaysia (Eltz et al., 2003) and in the Brazilian Amazon (Venturieri, unpubl. data) it has been shown that logging reduces stingless bees nests and, as a consequence, native pollinators, which has implications for forest recovery or restoration. Villanueva et al. (2005a) remarked that logging also reduces forest habitat that contains suitable, unoccupied nesting sites. Eltz et al. (2003) considered that the loss of pollinators occurs even if the rules for certified wood management are taken into account. In Brazil a Resolution approved by the Environmental Ministry National Council (CONAMA) in July 2004, which considers the protection and use of wild bees and establishment of meliponaries. The commercialization of native bees will be allowed only if produced from propagation of hived colonies, or those colonized naturally in artificial nests. This should help to eliminate the destruction of trees for extraction of living bee colonies. Nevertheless, the Brazilian government has not yet paid attention to the need for general pollinator conservation among the rules now being established for forest management.

Samejima et al. (2004) studied the effects of human disturbance (logging and shifting cultivation) on a stingless bee community in a tropical rainforest, in Sarawak, Malaysia. Nest density was positively related to the density of large trees. The bait results indicated that some species were abundant in the primary forests, whereas others were found mainly in disturbed forests. These authors emphasize the role of nest site availability as a limiting factor for nest density. In Borneo, the distribution of stingless bee nests is often clumped (Roubik, 1996, 2006; Nagamitsu and Inoue, 1997; Eltz et al., 2002).

\section{HONEY PRODUCTION}

The extraction of honey is often the sole income for keepers of stingless bees, followed by cerumen (Fig. 4) and resin, but a few years ago, commercial use of stingless bees in pollination began. In all Latin American countries,

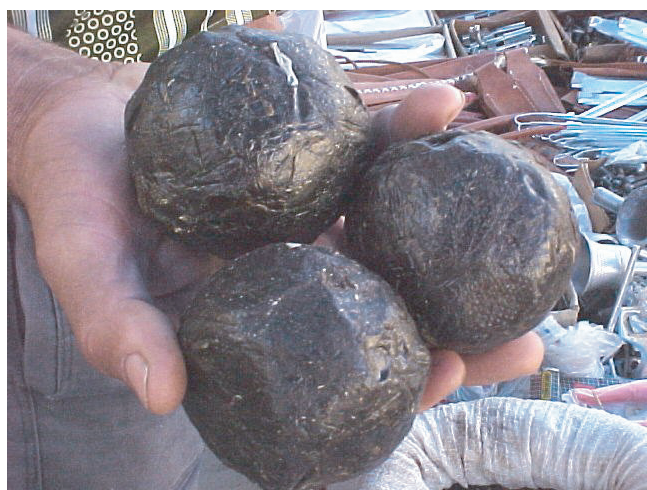

Figure 4. Balls of cerumen sold in street fair in the Northeast of Brazil (photo by M. CortopassiLaurino).

as elsewhere, stingless bee honey is used much more as medicine than as a sweetener.

Some farmers comment that they obtain exceptional honey production from old established colonies. The average yearly production is nearly one or two liters per colony, in standard hives (Tab. II). For M. subnitida, an exceptional production of nearly 6.0 liters/year occurred in a few colonies out of 80 during the rainy season in Caatinga regions of Brazil (Cortopassi-Laurino and Macêdo, 1998).

The tradition of selling stingless bee honey in Brazilian markets has become cost effective only recently. Small jars indicating stingless bee species of origin can be found in local markets in production areas. This honey carries a higher price than the honey of Apis. In specialty shops in big cities the price is around US \$40 per liter.

Today, although some beekeepers have more than 500 colonies, they have problems preserving the honey because it is watery and ferments very quickly. In a survey of different methods used to collect and conserve stingless bee honey, Silva (2005) concluded that the pasteurization method proposed by Nogueira-Neto (1997) could maintain most of the honey's original characteristics for six months. This method is thus an effective and simple way to conserve stingless bee honey for commercialization. The way honey is extracted and the use of sanitary measure necessary play an important role in its final use and price if selected for table or foods 
Table I. Region and country where stingless bees are being reared.

\begin{tabular}{|c|c|c|}
\hline Species of stingless bees & $\begin{array}{c}\text { Region where bee is reared } \\
\text { and or biome }\end{array}$ & Country \\
\hline $\begin{array}{l}\text { M. compressipes manaoensis } \\
\text { M. seminigra merrillae } \\
\text { M. rufiventris paraensis }\end{array}$ & Amazon (Amazonas) & Brazil $^{1}$ \\
\hline $\begin{array}{l}\text { Frieseomellita sp. } \\
\text { M. compressipes fasciculata } \\
\text { M. compressipes manaoensis } \\
\text { M.rufiventris flavolineata } \\
\text { M. melanoventer } \\
\text { M. seminigra pernigra } \\
\text { M. seminigra (Tapajós sub sp.) } \\
\text { Scaptotrigona nigrohirta } \\
\text { Tetragona clavipes } \\
\text { Tetragonisca angustula }\end{array}$ & Amazon (Pará, Maranhão) & Brazil $^{1}$ \\
\hline $\begin{array}{l}\text { M. crinita } \\
\text { M. eburnea fuscopilosa } \\
\text { M. flavolineata } \\
\text { M. grandis } \\
\text { Tetragonisca weyrauchi }\end{array}$ & Amazon (Acre) & Brazil $^{1}$ \\
\hline $\begin{array}{l}\text { M. compressipes fasciculata } \\
\text { M. fulva }\end{array}$ & Amazon (Amapá) & Brazil $^{1}$ \\
\hline $\begin{array}{l}\text { M. asilvai } \\
\text { Scaptotrigona } \mathrm{sp} \text {. } \\
\text { M. subnitida }\end{array}$ & Caatinga* (northeast) & Brazil $^{1}$ \\
\hline $\begin{array}{l}\text { M. rufiventris } \\
\text { M. scutellaris } \\
\text { M. quadrifasciata } \\
\text { Tetragonisca angustula }\end{array}$ & Atlantic Rain Forest (northeast and southeast) & Brazil $^{1}$ \\
\hline $\begin{array}{l}\text { Frieseomelitta varia } \\
\text { M. rufiventris } \\
\text { Scaptotrigona spp. } \\
\text { M. mandacaia } \\
\end{array}$ & Savanna (northeast) & Brazil $^{1}$ \\
\hline $\begin{array}{l}\text { M. beecheii } \\
\text { Frieseomelitta nigra } \\
\text { Scaptotrigona pectoralis }\end{array}$ & Yucatan & Mexico $^{2}$ \\
\hline Scaptotrigona mexicana & Puebla & Mexico $^{2}$ \\
\hline $\begin{array}{l}\text { Melipona fasciata } \\
\text { Tetragonisca angustula } \\
\text { Melipona beecheii } \\
\text { Scaptotrigona pectoralis } \\
\text { Scaptotrigona luteipennis }\end{array}$ & Guanacaste/Puntarenas & Costa Rica $^{1}$ \\
\hline $\begin{array}{l}\text { Melipona eburnea } \\
\text { Tetragonisca angustula } \\
\text { Tetragonisca weyrauchi }\end{array}$ & $\begin{array}{c}\text { Loreto } \\
\text { San Martin } \\
\text { Madre de Dios }\end{array}$ & Peru $^{3}$ \\
\hline $\begin{array}{l}\text { Scaptotrigona aff. polysticta } \\
\text { Scaptotrigona postica }\end{array}$ & Ibiato/Nguiray & Bolivia $^{4}$ \\
\hline Scaptotrigona depilis & Montevideo & Paraguay $^{5}$ \\
\hline $\begin{array}{l}\text { Tetragonisca angustula } \\
\text { Melipona favosa }\end{array}$ & Tachira & Venezuela $^{6}$ \\
\hline $\begin{array}{l}\text { Trigona carbonaria } \\
\text { Trigona hockingsi } \\
\text { Austroplebeia spp. }\end{array}$ & Queensland and New South Wales & Australia $^{1}$ \\
\hline
\end{tabular}

Data from ${ }^{1}$ : current authors; ${ }^{2}$ : Cortopassi-Laurino (2002); ${ }^{3}$ : Rassmussem and Castilho (2003); ${ }^{4}$ : Pinto pers. comm.; ${ }^{5}$ : Shevelev (2003);

${ }^{6}$ : Moreno et al. (2005).

Caatinga* a stunt sparse semi-arid region found in Northeast of Brazil. 
Table II. Production of honey/colony/year (liters) in Brazil.

\begin{tabular}{lcc}
\hline Bee & Average Honey (max) & Author \\
\hline M. asilvai & $1,0(2,5)$ & Carvalho et al. (2003) \\
M. fasciculata & $2,4(4,4) \mathrm{n}=19$ & Venturieri et al. (2003) \\
M. mandacaia & $2,0(4,0)$ & Carvalho et al. (2003) \\
M. quadrifasciata & $2,0(5,0) \mathrm{n}=50$ & Valdemar Monteiro (pers. comm.) \\
M. rufiventris & $3,0(5,0) \mathrm{n}=28$ & Lima Verde (pers. comm.) \\
M. subnitida & $2,5(5,6) \mathrm{n}=80$ & Ezequiel Macedo (pers. comm.) \\
M. scutellaris & $3,0(10,0) \mathrm{n} \geq 100$ & Francisco Chagas (pers. comm.) \\
Scaptotrigona postica & $1,5(3,0)$ & Carvalho et al. (2003) \\
Scaptotrigona nigrohirta & $3,8(12,0)$ & Venturieri \& Imperatriz-Fonseca (2000) \\
T. angustula & $1,0(2,7) \mathrm{n}=100$ & Jean Julien (pers.comm.) \\
\hline
\end{tabular}

industries. One campaign headed by Patricia Vit, from Venezuela, focuses upon honey quality and authenticity, strategic impacts in honey commercialization, and standard analysis of honey from stingless bees. Although most honey comes from Melipona and Tetragonisca angustula, there are many species of stingless bees that produce honey but remain understudied (Roubik, 1983; CortopassiLaurino and Gelli, 1991; Vit et al., 1994, 2004; Grajales et al., 2001; Bazlem, 2002; DeMera and Angert, 2004; Cortopassi-Laurino, 2005). Physico-chemical parameters, botanical origin, and microbiological conditions should be known at least for the potential species, to develop the needed legislation to allow the commerce and control of stingless bee honey. Nogueira-Neto proposes the name "irahoney" for this product (ira means bee in the native Tupi-Guarani language), to distinguish it from the honey produced by Apis mellifera, whose control and commercial rules do not apply to stingless bees.

It has been suggested by Vit et al. (2004) that honeys from all Melipona species could be included under only one legislation. To accept this idea, we still have to study and to test the honey of stingless bees that are now most widely bred in Brazil, which comprise at least 10 species (Tab. I). Also important is the consideration that the honey should be harvested under optimal conditions, which include ripened honey from closed storage pots and a special extraction machine, due to the high level of humidity and yeasts that are frequently observed in the honeys from stingless bees.
Honey production also depends on the quality of environment, competition with other bee species for floral resources, and bee management. Villanueva et al. (2005a) discussed this point in relation to honey production by Melipona beecheii. The destruction of natural areas and the increased number of Apis mellifera colonies had an impact on colony survival and honey production. These authors suggested that colonies were overexploited for honey collection and perished without adequate management. In early times honey was harvested 5 times a year, and the production was between 10 to 20 liters a year (Crane and Graham, 1985; Crane, 1992).

\section{REGIONAL ACCOUNTS OF MELIPONICULTURE}

\subsection{Meliponiculture in Mexico}

The remarkable feature of stingless bee beekeeping in Mexico is that, historically, it was the only sustainable type of beekeeping anywhere in the world. Nevertheless, the situation has changed in recent years, mainly concerning beekeeping with Melipona beecheii (Villanueva et al., 2005a).

Before providing some details which help explain the relationship between stingless bee beekeeping and management in Mexico, a brief survey of the bees is useful. The genera Melipona (which includes the largest stingless bees), Scaptotrigona and Cephalotrigona occur throughout tropical America (see Ayala, 1999). The first two are apparently the 
most widely cultivated for their honey. In Mexico, modern meliponiculture is almost entirely limited to Melipona beecheii and occasionally to $M$. solani in the lowlands, and includes M. fasciata and M. colimana in highland areas. Colonies of Scaptotrigona mexicana are maintained in clay jars in part of Mexico, as are $S$. hellwegeri and S. pectoralis. Cephalotrigona is next to Melipona in size and has three species in Mexico. Log hives of C. zexmeniae (sometimes called $C$. capitata in Central America) are kept by Mayan people in the Yucatan peninsula.

An increasing number of studies establish baseline numerical density and abundance of bee colonies in natural habitats (review by Kajobe and Roubik, 2006). Are the most abundant bee colonies those most likely to be utilized by man? Generally, bee nest surveys of stingless bees or Apis are made in secondary or old primary forests, and occasionally when there are obviously many bee colonies in more disturbed areas. First of all, the number of stingless bee colonies in older forests, anywhere in the world, is not particularly high. Usually one to four colonies exists per hectare. The lowest density has been found in old central Amazonian forest where within 100 ha only three colonies occurred. However, the numbers of species found nesting was nowhere near the number of local species (Oliveira, 2001), thus one might conclude that many colonies were too small or too far from the ground-level survey to be detected. Secondly, surveys in disturbed habitats (including cleared areas with buildings), or in very young forests, have registered the highest densities of colonies (Batista et al., 2003). Unfortunately, because there is not a uniform density of suitable nesting sites (like the tree hollows in a continuous forest) it is impossible to translate the densities of colonies per building or in semi-natural nest cavities (walls, holes, felled trees) to the density of nesting colonies on a habitat-wide basis. Vertical compression of all potential nesting sites (normally reaching above 30 to $40 \mathrm{~m}$ in the forest canopy) to buildings or vegetation that reaches only one-fourth this height, also makes the equivalence of nest surveys on a 'per area' basis doubtful. Nonetheless, the mean of the few dozen surveys provides an es- timate of approximately 2 colonies per hectare (Kajobe and Roubik, 2006). This data can be used to ask the next question: What kinds of colonies are found?

The Neotropical data reveal a strong tendency for most forests to contain many colonies of Scaptotrigona but few of Melipona. Unpublished nest survey data from the Yucatan peninsula (Gonzalez-Acereto, pers. comm.) concur with similar data from Panama, Costa Rica, and Bolivia. Scaptotrigona have the most numerous colonies of any stingless bee species with a relatively large body and colony size. Furthermore, colonies of Melipona have far fewer workers, perhaps $70-80 \%$ less, than Scaptotrigona. However, regarding honey stores in the nest, both genera can have several liters at any one time. It can be ascertained that Scaptotrigona and Melipona, Cephalotrigona, and Tetragona are the only Neotropical stingless bees that store so much honey. Thus, if Mexican habitats have been consistent in the forest bee colonies which they contain, either large bees, large honey stores, or high abundance - and probably a combination of these variables - have had marked influence on the stingless bee species selected for meliponiculture.

An incentive to humans for propagation of Melipona beecheii was probably a result of its low nesting density and prized honey stores. In traditional Mayan stingless bee beekeeping, up to five honey harvests were taken annually from $\log$ hives of $M$. beecheii in forested areas (Villanueva et al., 2005a). In that long-term study in the heartland of traditional Mayan meliponiculture, the original 27 colonies in a single meliponary were derived from a single parent or 'mother' colony. All those managed colonies have disappeared during the last 20 years. A regional decline of over $90 \%$ in managed colonies in the past half century was also documented. An explanation was that colonies are no longer propagated, while other factors, such as waning traditions and hurricane damage, exacerbate the depressing situation by increasing colony mortality.

The first techniques used for colony propagation in Mexico are unknown, but probably involved simple division of the brood and stored food into log hives. Log hives are 
hollow trees of an abundant hardwood; those currently in use in Yucatan are 'silicote' the same tree of the famed chicle trade Manilkara (Sapotaceae). The ends of the hollowed log are sealed with a firm, thick plate of the local limestone, and the cracks sealed with mud. The stone plugs are a unique asset, which require only a short time to produce from limestone rocks scattered on the surface of the entire Yucatan peninsula. Another unique asset of meliponiculture with Melipona is that the colonies continuously produce queens. A newly divided colony can thus usually possess a laying queen soon after it has been made by the beekeeper. Whether there had been a tradition of colony propagation using Scaptotrigona or Cephalotrigona is unknown. The current practice of dividing Scaptotrigona, often using brood from three donor nests, is possibly a recent advance in meliponiculture (Stierlin and Szabo, 2004; and Szabo and Stierlin, in press). The basic trial-and-error development of husbandry techniques had the best chances for success using the native Melipona that were readily hived and whose colonies were divided successfully using a minimum of technology or scientific knowledge. Although stingless bee beekeeping has progressed since the ancient Maya worked out some basic principles, many of the current techniques remain essentially unchanged.

\subsection{Meliponiculture in Costa Rica}

Stingless beekeeping in Central America originated among the Maya of the Yucatan Peninsula and spread to other Central American Indian cultures (Kent, 1984). Before the discovery and the conquest of American continent by Europeans (indigenous peoples immigrated across the Bering Strait at least 15000 years ago), rearing stingless bees was an important part of the commercial and alimentary customs of many indigenous cultures of America. The honey of these bees was used as food and medicine, and the preparation of other products based on cerumen was also important (Kent, 1984; Sommeijer, 1996). As in other Mesoamerican areas, stingless beekeeping in Costa Rica did not play an important role in the religion of indigenous cultures
(Kent, 1984). However, it was reported that an abundance of honey and wax was produced around the beginning of the 20th century (Kent, 1984).

The practice of the stingless bee beekeeping in Pacific Costa Rica (Nicoya) was considered popular (Kent, 1984). Nowadays, the practice of the meliponiculture in that region is less prevalent. Other areas belonging to Puntarenas and Guanacaste provinces (Santa Cruz, Hojancha, Filadelfia, and Miramar) are known for traditional meliponiculture. In other regions of Costa Rica meliponiculture is less common, compared with Guanacaste and Puntarenas. For instance, in the Atlantic region of Limón and Alajuela, we have observed few stingless beekeeper but many of them have received motivation during our recent workshops.

The stingless beekeepers usually keep their colonies in log hives, generally hanging under the roof of their houses. Special places for keeping the colonies are built away from the house, and in exceptional cases there are more than 40 colonies. The farmers that do not have land or a higher educational degree constitute the main social group involved in meliponiculture.

Stingless bee beekeeping in Costa Rica has been practiced at a low technical level, almost without equipment, and the type of hive used is mainly a hollow log (Arce et al., 1994). The main species reared are "jicote gato" (M. beecheii), "jicote barcino" (M. fasciata) (Melipona costaricensis), "mariquita o mariola" (Tetragonisca angustula), "soncuano" (Scaptotrigona pectoralis pectoralis) and "tacanique" (Scaptotrigona luteipennis) (Ramírez and Ortiz, 1995). The breeding of Frieseomelitta nigra, T. fulviventris, Lestrimelitta, and Plebeia tica is less common. Lestrimellita, a robber bee that does not visit flowers, is not suitable for stingless bee beekeeping (Santana et al., 2004).

Arce et al. (1994) reported from a survey of 40 stingless bee beekeepers (Guanacaste Province) a total of 9 different domesticated species: M. beecheii, M. fasciata (now known as M. costaricensis) M. fuliginosa, Tetragonisca angustula, Scaptotrigona pectoralis, Cephalotrigona capitata, Nannotrigona perilampoides, Trigonisca, 
Frieseomelitta, Oxytrigona mellicolor, and Tetragona. Some farmers obtained production of up to 6 liters and, in the case of M. beecheii, the production average was 2.63 liters per hive.

According to van Veen et al. (1990), meliponiculture in Costa Rica is practiced basically in two ways: (1) maintaining the nests in tree trunks, from which the honey, by a lateral opening, is extracted, generally used for $M$. beecheii; and (2) maintaining the colonies in small boxes, pieces of bamboo or hollow gourds, ordinarily with $T$. angustula. Although meliponiculture occurs throughout Costa Rica and even in urban areas (Sommeijer, 1996), the local people do not understand the reproductive biology of the bees. This is reflected in the fear the people have in dividing nests. When carried out in a haphazard way, nest division results in parasite attack (phorid flies) and loss of the colony.

In relation with the design and dimensions of hive boxes, van Veen et al. (1993) recommended for $M$. beecheii a hive with a volume of 10 liters with internal dimensions of $15 \mathrm{~cm}$ height, $15 \mathrm{~cm}$ width and $45 \mathrm{~cm}$ length. For $T$. angustula the recommended box measures $15 \mathrm{~cm} \times 15 \mathrm{~cm} \times 20 \mathrm{~cm}$ long, which gives a volume of 4.5 liters. In its application we have observed that the stingless beekeepers modify the dimensions of hives according to the species and the size of the colony.

Thanks to different extension projects and workshops carried out by the Tropical Beekeeping Research Center (CINAT) Universidad Nacional, Heredia, Costa Rica the interest in this honey and in stingless bees has increased over the past few years. Today commerce of this honey commands high prices; one liter sells for US \$20-50 and small containers of $10 \mathrm{~mL}$ cost US $\$ 2.0$ due to an increasing interest in its medicinal use (mainly used against cataracts).

Research carried out by CINAT confirmed the importance of Nannotrigona perilampoides and Tetragonisca angustula as pollinators of the ornamental plant Salvia farinacea (Slaa et al., 2000). This stingless bee can be considered an alternative to honey bees for commercial crop pollination. Also, there is a study on the influence of altitude on the distribution of stingless bees by Ortiz-Mora and van
Veen (1995), in Guanacaste Province Costa Rica, where fewer species were collected at higher altitudes. It is well known that stingless bee species richness declines dramatically above $1000 \mathrm{~m}$ in Central America. They are more abundant at 200-500 $\mathrm{m}$ and rare at 700 1000 m. van Veen et al. (2004) studied in Costa Rica the production of queens and drones for $M$. beecheii in relation to food storage, brood and adult populations. They found that the colonies grow at the end of the rainy season, which is a period characterized by poor foraging conditions. On the other hand they found a significant correlation between the amount of pollen stored and the production of queens and drones. Finally, more action should be taken to continue the work initiated by Wille (1961) on the biology, biodiversity conservation and management of the stingless bees in Costa Rica.

A cooperative programme for research, extension and training related to tropical bees (PRAM) involving Utrecht University and the Universidad Nacional de Costa Rica began in 1990 (www.una.ac.cr/cnat/conven2.htm) and more recently El Salvador joined the group.

\subsection{Meliponiculture in Brazil}

Meliponiculture in Brazil was studied and summarized by Nogueira-Neto (1953, 1970, 1997, 2002) and Kerr et al. (1996), who promoted development of this activity. Besides advancing the activity with guidebooks, which provide a unique literature in Portuguese, these investigators' research resulted in a group of scientists that also work with meliponiculture and Brazilian stingless bees.

Theories of genetic variability (Kerr and Vencovski, 1982; Kerr, 1985) predicted that to successfully breed stingless bees it was necessary to have at least 44 colonies, to avoid diploid males created by excessive inbreeding in the population. From 1990 to 2001, Nogueira-Neto (2002) performed 287 colony divisions, starting with 28 foundress colonies. Seven species of stingless bees (and one subspecies) were inbred in five localities inside their extensive native habitats, and in two localities far from these habitats. On the whole, the number of colonies increased and the loss 
of colonies over the years was small. Diploid males were not found in nests after several divisions. This investigator also evaluated how long a queen lived in some species, by marking physogastric queens with a dot of permanent paint. Most colonies changed queens every year. The experiments continue, and it is clear that we need more research on the genetics of stingless bee populations. Furthermore, the survival of small populations is a conservation concern. Nogueira-Neto is testing management techniques that are locally adapted to stingless bees. Phorid flies are controlled with the use of vinegar traps, first constructed by Imperatriz-Fonseca. These are often very effective in control. Nowadays they can be used inside the nest, as well as outside.

In early times, beekeepers collected stingless bee nests in nature, as did their relatives and parents. More recently they are learning how to divide the colonies, as well as become more conscious of environmental concerns. In Brazil, with few exceptions, beekeepers maintain a low technical level, almost without equipment. The harvest of honey is often made by shaking the hives upside-down, thereby destroying young larvae that fall from their provisions, and also attracting phorid flies that damage and parasitize the nest.

Honey, new colonies and nuclei (small incipient colonies) are the main products of Brazilian meliponiculture. Stingless bee beekeeping as a hobby and for educational purposes is another strong reason to keep these bees in urban or rural areas.

Surveys carried out in 2001 by Rosso et al. (2001). in Brazil showed that meliponiculture is growing rapidly, and for most people it is a secondary economic activity. Most of these beekeepers rear stingless bees from their natural regions, but for only one person surveyed the sale of new colonies or nuclei, and honey, was the only family income. One beekeeper (a breeder of Melipona scutellaris) increased the number of his colonies from 200 (in 2001) to 750 (in 2006). Another breeder from Central Amazon, keeping Scaptotrigona sp. and other five species of Meliponini, increased the number of colonies from 45 in 2000 to 350 in 2005 after adoption of vertical rational hives (similar to the one shown in Fig. 1). This beekeeper also adjusted the measurements of the box for each bee species.

The way a stingless bee beekeeper divides and propagates colonies varies according to species and husbandry knowledge (NogueiraNeto, 1997). A curiosity to mention here is the beekeeper that successfully divides the nests of M. scutellaris using a large knife, cutting the nests vertically in two parts. Three main ways of splitting the nests are known, using one, two or more colonies in order to form a new one, although the adult workers come from only one nest (Cortopassi-Laurino and Macêdo, 1998).

Most Brazilian stingless bee beekeepers are members of associations and cooperatives, and some of them have their own homepages. The oldest is CAPEL, in Pernambuco state. Blogs or discussion websites are also available for stingless bee beekeepers, generally used for beginners, which facilitates the spread of general beekeeping techniques.

In Brazil, a dozen beekeepers started rearing stingless bees as part of social and governmental projects. The largest is Iraquara Project in Amazonas state, which produced 3 tons of honey in 2004 (Villas-Bôas and Malaspina, 2005). In the last three years, the Brazilian Agricultural Research Company (EMBRAPA) has trained more than 450 rural workers, students, and technicians in meliponiculture in Northeastern Amazon. After implementation of these courses, the number of bee boxes increased from 281 in 2003 to over 900 in 2005 by the same group of beekeepers. Many of these beekeepers also commercialized part of their colony divisions, and thus helped spread the meliponiculture practice.

Research with stingless bees for use as pollinators exists in Brazil. Malagodi-Braga and Kleinert (2004) verified the importance of Tetragonisca angustula as effective pollinators for some strawberry cultivars. Additional studies concerning stingless bees as pollinators are in place (Venturieri et al., 2005). Slaa et al. (2006) reviewed this point.

\subsection{Meliponiculture in Africa}

Stingless bee taxonomy has recently been reviewed by Eardley (2005). There are over 
20 stingless bee species in Africa, but much work remains to be done. Stingless bee studies were conducted by Bassindale (1955), who studied Hypotrigona; Darchen (1972) studied several species, and also made films on African stingless bees, available in www.cerimes.education.fr. Breeding and meliponiculture in Africa was considered by Portugal-Araujo (1957) in Angola, but this practice did not evolve in subsequent years.

African stingless bee honey is mostly collected by harvesting from feral colonies, which subsequently destroys them. A few communities use hollow logs or clay pots as hives, and they harvest the honey in a more sustainable way. In at least Tanzania, and Angola, meliponiculture exists and an interest to develop meliponiculture has been identified in Ghana, Kenya, Botswana and South Africa. In Angola, Meliponula bocandei, the largest stingless bee, produces $10-15 \mathrm{~kg}$ of honey in a season (Armor, 2005).

\subsection{Stingless beekeeping in Australia}

In Australia 20 years ago, few beekeepers had more than one or two stingless bee hives. Today, there is a growing interest in nest conservation. Crop pollination services are developing, honey and cerumen are being harvested, and a stingless bee industry is being developed by the indigenous community. Bees also are being used for public education.

There is a growing interest in conserving wild stingless bee colonies. Many individual beekeepers relocate nests found in fallen trees and artificial sites. In Ipswich, Queensland, a rescue group led by $\mathrm{C}$. Heather actively identifies land about to be cleared for development and seeks permission to remove nests that would otherwise be destroyed. Over a sevenyear period this group has rescued 200 stingless bee nests. Once wild colonies are captured in hives, they can be allowed to reproduce. Indeed, the increase in popularity of the bees in Australia over the last 20 years is partly due to the development of a husbandry method (Heard, 1988). Colony multiplication is infrequent, typically every one to two years, but population growth is exponential.
A survey of stingless bee keeping in Australia in 1998-99 concluded that 62 beekeepers kept 317 hives of stingless bees for crop pollination (Heard and Dollin, 2000). However, only one beekeeper, with 65 hives, was offering crop pollination service. Now, in 2005, at least six beekeepers offer stingless bee services for crop pollination, usually as their secondary financial activity. Those beekeepers have 15 to 150 hives. Many crop growers are also purchasing their own stingless bee colonies. The main species used for crop pollination are Trigona carbonaria and T. hockingsi.

Macadamia nut (Macadamia integrifolia), native to eastern Australia, is the most common crop pollinated with stingless bees. With over 800 farms, Australia is the world's largest producer of macadamia nuts. Stingless bees mainly collect pollen from the flowers and are efficient pollinators (Heard, 1994). Many other crops may be pollinated by stingless bees (Heard, 1999) and in Australia, successful results for lychee, melon and avocado have been reported. Wild stingless bees often provide a free pollination service (Heard and Exley, 1994) but where the bees are rare because of land clearing, hives need to be introduced.

Australian stingless bees prefer to forage close to their hives, thus tend to stay within the crop area better than does Apis (Carter, pers. comm.). One beekeeper reports that the effective foraging range of stingless bees within a macadamia crop is $25 \mathrm{~m}$ (Adcock, pers. comm.). Stingless bees also cope better than Apis in crops covered by netting (Felhaber, pers. comm.). However, stingless bees can be quite sensitive to pesticides, which can result in substantial bee losses (Grosskopf, pers. comm.).

Demand for crop pollination services with stingless bees in Australia should continue to increase as farmers become informed of the benefits and more hives become available. Small hive beetles (Aethina tumida) that are progressively spreading through New South Wales and Queensland may deplete feral Apis populations, increasing demand for paid pollination services. Varroa mite is also threatening to enter Australia and will also reduce Apis populations. 
In addition to crops, native bushland requires pollination services. The pollinators may have been driven extinct by human induced pressures. Some interest is being expressed by managers of bushland to reintroduce stingless bees into conservation areas.

Interest in production and marketing of Australian honey is growing. New hive designs that are suited to the extraction of honey and cerumen are being developed. Interest in the honey is being expressed by restaurants that promote native foods. We estimate that the total current annual production in Australia is extremely small, possibly less than $100 \mathrm{~kg}$, but there is potential for rapid growth. The market price of the honey is currently about AU $\$ 50$ per $\mathrm{kg}$, wholesale. To develop commercially, the price needs to increase, because the production per hive is low and the cost of production is high. Challenges include minimizing fighting swarms and nest parasites (Dollin, 2002).

Russell and Janine Zabel have been working with the indigenous community of $\mathrm{Au}$ rukun in far north Queensland since 2002 to develop a stingless bee industry. Currently they have hived over 130 colonies, mostly T. hockingsi. Stingless bee honey, known to indigenous people as 'Sugarbag', is a major product. Cerumen is also collected for making traditional artifacts (Zabel, pers. comm.). A major potential use for the cerumen is to form the mouthpiece of the "didgeridoo", a traditional musical instrument. Until recently, cerumen was very difficult to obtain and honey bee wax was used as a substitute. However, stingless bee cerumen is the authentic and superior product. Demand is expected to grow rapidly as awareness increases.

Stingless bees are attractive subjects for public nature education. Museums, exhibitions, gardens, and schools in Australia are increasingly using social bee colonies to illustrate the beauty, complexity and fascination of nature. Topics such as sociality, parasitism and pollination can be demonstrated using these insects, which are gentle and easy to keep. The Melbourne Museum maintains a permanent indoor public display by only occasionally exchanging the colony with another outside. The
Brisbane Botanic Gardens has a demonstration $\log$ nest, which they use as part of their education program. Workshops on stingless bees at nature education centers are growing in popularity. The Australian Native Bee Research Centre has a site at www.aussiebee.com.

\subsection{Meliponiculture in Asia}

Southeast Asia has several honey bee species and about 45 stingless bee species, but nowhere is there a standard practice called meliponiculture. Thailand, like Viet Nam, is a very long country, extending for over $1000 \mathrm{~km}$ south to north. In the south, there are five Apis species and at least 30 stingless bee species, while in the north, there are four Apis and less than 10 stingless bee species. The southern Thai name for meliponines is "Oong", while in the north, they are called "Channa Long". The honey bees are called "Png". The local people only use stingless bee honey for "medicinal purposes" because they say it is a lot of work to remove the honey from a tree or subterranean nest of stingless bees. In contrast, they can obtain several liters of honey from a nest of Apis dorsata or Apis cerana, and many nests of the former can be harvested on a single tree. There is also traditional use of wax from the nests of Apis dorsata in batik fabric design, so that there is a steady demand for honey hunting, using both the comb and the honey, from the giant honey bee. The local stingless bees have so little to offer, by comparison, that it does not occur to anyone that the keeping of stingless bees in hives is worth the trouble. Stingless bee beekeeping for pollination service is only now beginning to take root in southern Asia (in India) and in SE Asia (Malaysia and the Philippines).

\section{LARGE-SCALE BEEKEEPING WITH STINGLESS BEES}

In Brazil a large quantity of colonies has yet to become available, for instance, to be sold for agricultural use or for use as greenhouse pollinators. To have a system similar to that of Bombus terrestris (Velthuis and van Doorn, 
2004), additional information on queen production is needed, as well as controlled mating and colony propagation techniques under artificial conditions. Until now queen emergency cells for stingless bees have been found only in Frieseomellita varia (Faustino et al., 2002), which allow the propagation of many colonies in this genus. A similar finding for other stingless bees species, such as Frieseomelitta, which construct brood cells in clusters, would be nothing short of revolutionary.

Generally a large number of gynes (potential laying queens) is available only for Melipona bees, where gynes, workers and males emerge from similar brood cells. Recent review (see Santos et al., 2006) shows that Melipona queens are produced in a smaller number than presumed before, and only a few number of other stingless bees has been studied in relation to gyne and male production (Chin and Sommeijer, 2005). Another perspective is related to miniature gyne production (Ribeiro et al., 2006).

\section{CONCLUSIONS AND RECOMMENDATIONS}

Stingless bee breeding is a significant activity that permits sustainable agricultural development and wildlife conservation, but for many species it requires specific management techniques and intact natural environments. Villanueva et al. (2005a) mentioned the concerns that no new colonies were available for Melipona beecheii in the studied area; bees are dying from lack of food; colonies have less and less honey, and colonies are diminishing in size. These are likely to be the same problems faced by meliponiculture elsewhere in the world.

Stingless bee beekeeping, at least in some areas, is disappearing. The younger potential beekeepers must join the effort in maintaining the population of stingless bees. Basic biology studies are needed, mainly concerning the exploitation of natural resources by these bees and medium-long-term studies. The new meliponiculture will be organized to ideally provide agriculture and wildlife with the ecosystem services essential for pollination.
In all places where meliponiculture develops, bottlenecks for their improvement include how to keep and conserve their honey, how to rear them in large quantities, how to prevent colonies from being contaminated by agricultural pesticides and maintain the bees, how to use their services and conserve their populations, and how to provide qualified information and training in all levels.

Résumé - Méliponiculture globale : défis et chances. Les abeilles sans aiguillon (Apidae, Meliponini) sont des insectes sociaux qui vivent dans les régions tropicales et subtropicales du globe. L'importance de leurs produits en Amérique latine, principalement le miel (utilisé comme édulcorant et comme remède), est souligné. Il existe des documents écrits, principalement les codex mayas, qui montrent le rôle central des abeilles sans aiguillon dans la vie religieuse et culturelle. Melipona beecheii est la première abeille dont l'élevage en grand a été mentionné : elle est élevée dans des troncs d'arbre regroupés en " méliponaires", ruchers pouvant réunir plusieurs centaines de leurs colonies. Maintenir des abeilles dans des troncs d'arbre a été la première étape de l'élevage dans plusieurs régions du monde où les abeilles sans aiguillon sont indigènes. L'étape suivante a consisté à diviser les colonies. L'utilisation moderne de ces abeilles va les considérer surtout comme fournisseurs de services pour l'environnement et comme pollinisateurs. Il s'agit d'un nouveau défi et d'une occasion pour approfondir leur connaissance et leur utilisation et pour travailler à leur sauvegarde.

On trouve la méliponiculture principalement dans les pays où cette activité est traditionnelle. Les colonies passent toujours de génération en génération, mais leur importance dans la vie moderne diminue. D'autres sources de sucre, comme la canne à sucre et le miel d'Apis mellifera, sont meilleur marché. On n'a pas mis au point de techniques de sélection des abeilles sans aiguillon et seules quelques espèces indigènes sont élevées, dont un genre très prometteur, Scaptotrigona. Ces abeilles sont également élevées dans des ruches en argile au Mexique, ainsi qu'au Brésil et en Afrique. Le déclin de la méliponiculture au Mexique et la survie de M. beecheii suscitent des inquiétudes. La situation au CostaRica est discutée. Ce pays améliore la méliponiculture par l'éducation à l'environnement et un travail avec les petits agriculteurs. Un groupe technique issu d'une coopération internationale a été mis en place afin de fournir un appui scientifique à cette activité. Le Brésil possède une tradition apicole avec les abeilles sans aiguillon. Les indigènes utilisaient ces abeilles, et cette connaissance a traversé les générations, comme chez les indiens Kayapo récemment étudiés. La méliponiculture s'améliore 
au Brésil; les apiculteurs sont généralement regroupés en associations et échangent leurs connaissances pratiques. Le miel est le principal produit, il est cher et apprécié comme remède. En Afrique et dans le sud-est asiatique, l'apiculture avec les abeilles sans aiguillon est confrontée à l'apiculture avec les abeilles du genre Apis, plus efficace pour le commerce. Dans ces régions la connaissance des abeilles sans aiguillon en est à ses débuts. En Australie les services commerciaux de pollinisation des cultures commencent à être fournis par des apiculteurs qui ont jusqu'à 150 ruches. Le macadamia (qui fournit la noix) est la culture plus courante à être pollinisée et la production de miel et de cérumen est en augmentation.

Partout où la méliponiculture se développe, les goulets d'étranglement sont : (i) comment conserver le miel des abeilles sans aiguillon, (ii) comment les élever en grandes quantités, (iii) comment faire des traitements insecticides et maintenir les abeilles, (iv) comment utiliser leurs services et préserver leurs populations et (v) comment fournir une information de qualité et une formation à tous les niveaux.

méliponiculture / abeille sans aiguillon / élevage / pollinisation / miel / cire / Apidae / Meliponini

Zusammenfassung - Globale Meliponikultur: Herausforderungen und Chancen. Stachellose Bienen sind soziale Bienen, die in den Tropen und Subtropen der gesamten Welt verbreitet sind. Die Bedeutung ihrer Produkte, vor allem Honig (als Süssstoff und Medizin) ist besonders in Südamerika deutlich. Schriftdokumente, vor allem die Maya Codices, zeigen die zentrale Rolle Stachelloser Bienen im religiösen und kulturellen Bereich. Melipona beecheii war die erste Bienenart, die in grossen Völkerzahlen gehalten wurde. Es wird von Meliponarien mit hunderten von Kolonien in Baumklötzen berichtet. Die Haltung von Bienen in Klotzbeuten war der erste Schritt zu ihrer landwirtschaftlichen Nutzung in vielen Teilen der Welt, in denen Stachellose Bienen vorkommen. Der nächste Schritt war die Teilung der Kolonien. Die Nutzung im modernen Sinn zielt vor allem auf die Rolle dieser Bienen als Lieferanten von Ökosystemdiensten, wie z.B. Bestäubung. Dies stellt eine neue Herausforderung dar und liefert auch Chancen für ihr Studium, ihre Nutzung und Konservierung.

Meliponikultur findet man heute vor allem in den Ländern in denen diese Aktivität eine Tradition hat. Mexiko war das erste Land. Kolonien werden hier immer noch über Generationen hinweg weitergegeben, aber ihre Bedeutung im modernen Leben nimmt ab. Andere Zuckerquellen wie Rohrzucker und Apis mellifera Honig sind im allgemeinen kostengünstiger. Zuchtmethoden für Stachellose Bienen wurden so gut wie nicht entwickelt und es werden nur einige native Arten gehalten, einschliesslich die in unserem Zusammenhang interessante Gattung Scaptotrigona. Ausser in Klotzbeuten werden diese Bienen in Mexiko, Brasilien und Afrika auch in Tonbeuten gehalten. In der vorliegenden Arbeit zeigen wir, wie die traditionelle Meliponikultur in Mexiko abnimmt und wie sich das auf das Überleben vom $M$. beecheii auswirken kann. Wir diskutieren ausserdem die Situation in Costa Rica, wo die Meliponikultur in Zusammenhang mit der Umwelterziehung und Arbeiten mit Kleinbauern zunehmend Bedeutung gewinnt. In diesem Land wurde über eine internationale Zusammenarbeit eine Expertengruppe aufgebaut, die diese Aktivitäten wissenschaftlich unterstützt. Brasilien hat eine Tradition in der Haltung Stachelloser Bienen. Eingeborenenstämme nutzen diese Bienen und geben, wie kürzlich für die Kayapo-Indianer gezeigt, dieses Wissen über Generationen hinweg weiter. Die Meliponikultur in Brasilien ist in einer Aufschwungsphase und Imker sind in der Regel in Imkergemeinschaften assoziiert und tauschen ihr praktisches Wissen aus. Der Honig Stachelloser Bienen ist teuer und wird gerne auch als Medizin verabreicht. Afrika und Südostasien sind Regionen in denen die Haltung Stachelloser Bienen mit den in wirtschaftlicher Hinsicht wichtigeren Honigbienen konfrontiert sein sollte, und in diesen Regionen steckt die Kenntnis Stachelloser Bienen noch in den Kinderschuhen. In Australien werden Stachellose Bienen jetzt von Imkern mit bis zu 150 Völkern zur Bestäubung kommerzieller Früchte eingesetzt, vor allem Makadamia. Zudem ist die Produktion von Honig und Cerumen im Anstieg begriffen.

An allen Orten, an denen die Meliponikultur in Ausbreitung ist, liegen die Engpässe ihrer Entwicklung darin, wie der Honig Stachelloser Bienen konserviert werden kann, wie Völker in grosser Anzahl gezüchtet, wie Pestizide appliziert und die Bienen gehalten werden können, wie ihre Dienste genutzt und Populationen konserviert werden können und wie qualifizierte Information und Schulung auf allen Ebenen verbreitet und betrieben werden kann.

\section{Meliponikultur / Stachellose Bienen / Bienen- zucht / Honig / Wachs / Bestäuber / Apidae / Me- liponini}

\section{REFERENCES}

Arce A.H.G., van Veen J.W., Sommeijer M.J., Ramírez A.J.F. (1994) Aspectos técnicos y culturales de la crianza de abejas sin aguijón (Apidae: Meliponinae) en Costa Rica, in: Veen Van J.W., Arce H.G., Ortiz R.A. (Eds.), Apicultura: Estrategias para el manejo adecuado de las colmenas Memorias del III Congreso Nacional de Apicultura, San José, Costa Rica, pp. 7-17. 
Armor M. (2005) Stingless Bees in Angola, [online] http://www.beesfordevelopment.org/info/info/stingless/stingless-bees-in-angola.shtml (accessed on 17 February 2006).

Ayala R. (1999) Revisión de las abejas sin aguijón de México (Hymenoptera: Apidae: Meliponini), Folia Entomol. Mex 106, 1-123.

Bassindale R. (1955) The biology of the stingless bee Trigona (Hypotrigona) gribodoi Magretti. Proc. Zool. Soc. 125, 49-62.

Batista M.A., Ramalho M., Soares A.E.E. (2003) Nesting sites and abundance of Meliponini (Hymenoptera: Apidae) in heterogeneous habitats of the Atlantic rain forest, Bahia, Brazil. Lundiana 4, 19-23.

Bazlem K. (2002) Charakterisierung von Honigen Stachelloser Bienen aus Brasilien. Thesis, Fakultät für Biologie der Eberhard-KarlsUniversität, Tübingen aus Stuttgart, Deutschland.

Byarugaba D. (2004) Stingless bees (Hymenoptera, Apidae) of Bwindi impenetrable forest, Uganda and Abayanda indigenous knowledge, Int. J. Trop. Insect Sci. 24, 117-121.

Camargo J.M.F., Posey D.A. (1990) O conhecimento dos Kayapó sobre as abelhas sociais sem ferrão (Meliponinae, Apidae, Hymenoptera): notas adicionais, Bolm. Mus. Paraense Emilio Goeldi 6, $17-42$.

Carvalho C.A.L., Alves R.M.O., Souza B.A. (2003) Criação de abelhas sem ferrão: aspectos práticos, DAS/DDP and Univ. Federal de Bahia, Salvador, BA.

Castro M.S. (2005) A criação tradicional de abelhas sem ferrão em potes de barro em Boninal, Chapada Diamantina, Bahia. Mensagem Doce 80, 38-43. [online] http://www.apacame.org.br/mensagemdoce/80/meliponicultura2.htm (accessed on 17 February 2006).

Chin T.X., Sommeijer M.J. (2005) Production of sexuals in the stingless bee Trigona (Lepidotrigona) ventralis flavibasis Cockrell (Apidae, Meliponini) in northern Vietnam, Apidologie 36, 493-503.

Cobo B. (1653) Historia del Nuevo Mundo, Biblioteca de Autores Españoles, XCI, Madrid.

Cortopassi-Laurino M. (2002) Relatos de viagem II: Meliponicultura no México, Mensagem Doce 66, $8-15$.

Cortopassi-Laurino M. (2005) Mieles de Meliponineos: Situación Actual y Desafios in IV Seminario y Taller Mesoamericano sobre abejas sin aguijón, El Salvador.

Cortopassi-Laurino M., Macedo E.R.M. (1998) Vida da Abelha Jandaíra Melipona subnitida, in Anais do XII Congr. Brasil. Apic. Salvador, Bahia.

Cortopassi-Laurino M., Gelli D.S. (1991) Analyse pollinique, proprietés physico-chimique et action antibactérienne des miels d'abeilles african- isées Apis mellifera et des Méliponines du Brésil, Apidologie 22, 61-73.

Crane E. (1992) The past and present status of beekeping with stingless bees, Bee World 73, 2942 .

Crane E., Graham A.J. (1985) Bee hives in the ancient world, Bee World 66, 148-170.

Darchen R. (1972) Écologie de quelques trigones (Trigona sp.) de la savane de Lamto (Cote d'Ivoire), Apidologie 3, 341-367.

De Jong H. (2001) La Meliponicultura en la Cosmovision Maya in Memórias do II Seminário Mexicano sobre Abejas sin Aguijón, Yucatán, Mexico, pp. 10-18.

DeMera J.H. Angert E.R. (2004) Comparison of the antimicrobial activity of honey produced by Tetragonisca angustula (Meliponinae) and Apis mellifera from different phytogeographic regions of Costa Rica, Apidologie 35, 411-417.

Dollin A.E. (2002) Tips on stingless beekeeping by Australian beekeepers, Vol. 3, Australian Native Bee Research Centre, Sydney, Australia.

Eardley C.D. (2005) Taxonomic revision of the African stingless bees (Apoidea: Apidae: Apinae: Meliponini), Afr. Plant Prot. 10, 64-74.

Eltz T., Brühl C.A., Kaars S., Linsenmair E.R. (2002) Determinants of stingless bees nest density in lowland dipterocarp forests of Sabah, Malaysia, Oecologia 131, 27-34.

Eltz T., Brühl S., Imiyabir Z., Linsenmair K.E. (2003) Nesting and nest trees of stingless bees (Apidae, Meliponini) in lowland dipterocarp forests in Sabah, Malaysia, with implications for forest management, For. Ecol. Manage. 172, 301-313.

Faustino C.D., Silva-Matos E.V., Matheus S. (2002) First record of emergency queen rearing in stingless bees (Hymenoptera, Apinae, Meliponinae), Insectes Soc. 49, 111-113.

Grajales C.J., Rincon R.M., Vandame R., Santiesteban N.A., Guzman A. (2001) Caracteristicas físicas, químicas y efecto microbiológico de mieles de meliponineos y Apis mellifera de la region Soconusco, Chiapas in Memórias del II seminário Mexicano sobre Abejas sin Aguijón. Mérida, Yucatán, México, pp. 61-66.

Heard T. (1988) Propagation of hives of Trigona carbonaria Smith (Hymenoptera, Apidae), J. Aust. Entomol. Soc., 27, 303-304.

Heard T.A. (1994) Behaviour and pollinator efficiency of stingless bees and honey bees on macadamia flowers, J. Apic. Res. 33, 191-198.

Heard T.A. (1999) The role of stingless bees in crop pollination, Annu. Rev. Entomol. 44, 183-206.

Heard T.A., Exley E.M. (1994) Diversity, abundance and distribution of insect visitors to macadamia flowers, Environ. Entomol. 23, 91-100. 
Heard T.A., Dollin A.E. (2000) Stingless bee keeping in Australia: snapshot of an infant industry, Bee World 81, 116-125.

Inoue T., Nakamura K., Salmah S., Abbas I. (1993) Population dynamics of animals in unpredictablychanging tropical environments, J. Biosci. 18, 425-455.

Kajobe R., Roubik D.W. (2006) Honey-making bee colony abundance and predation by Apis and humans in a Uganda forest reserve, Biotropica 38, 210-218.

Kent R. (1984) Mesoamerican stingless beekeeping, J. Cult. Geogr. 4, 14-28.

Kerr W.E. (1985) O número máximo e mínimo de colônias de meliponíneos que devem ser colocados em um local, Bolm. Capel 40. Belo Horizonte.

Kerr W.E., Vencovsky R. (1982) Melhoramento genético em abelhas. I. O efeito do número de colônias sobre o melhoramento, Rev. Bras. Gen. 5, 279-285.

Kerr W.E., Carvalho G.A., Nascimento V.A. (1996) Abelha uruçu, biologia, manejo e conservação, Fundação Acangaú, Belo Horizonte.

López G. (1552) Historia general de las indias cited in: Lóren J.J., Gómez J.J. (Eds.), Historia de la Apicultura Española, pp. 169-192.

Malagodi-Braga K., Kleinert A.P. (2004) Could Tetragonisca angustula Latreille (Apinae, Meliponini) be used as strawberry pollinator in greenhouses? Aust. J. Agric. Res. 55, 771-773.

Martins C.F., Cortopassi-Laurino M., Koedam D., Imperatriz-Fonseca V.L. (2004) Espécies arbóreas utilizadas para nidificação por abelhas sem ferrão na caatinga (Seridó, PB; João Câmara, RN), Biota Neotropica 4, No. 2, english version (Tree species used for nidification by stingless bees in Brazilian caatinga) online http://www.biotaneotropica.org.br/v4n2/pt/ fullpaper?bn00104022004+en (accessed on 17 February 2006).

Moreno F.E., Casanovo O.R., Diaz J.L. (2005) La meliponicultura y la tradición de uso de la abejas sin aguijón (Hymenoptera: Meliponinae) en el Estado Táchira, Congresso Internacional de Apicultura de los Andes, Venezuela UNET, pp. 61-70.

Nagamitsu T., Inoue T. (1997) Aggressive foraging of social bees as a mechanism of floral resource partitioning in an Asian tropical rainforest, Oecologia 110, 432-439.

Nogueira-Neto P. (1953) A criação de abelhas indígenas sem ferrão. 1a. ed. Chácaras e Quintais, SP, Brasil.

Nogueira-Neto P. (1970) A criação de abelhas indígenas sem ferrão, Editora Tecnapis, SP, Brasil.
Nogueira-Neto P. (1997) Vida e Criação de Abelhas Indígenas sem Ferrão, Editora Tecnapis, SP, Brasil.

Nogueira-Neto P. (2002) Inbreeding and building up small populations of stingless bees, Rev. Bras. Zool. 19, 1181-1214.

Oliveira M.L. (2001) Stingless bees (Meliponini) and orchid bees (Euglossini) in terra firme tropical forests and forest fragments, in: Bierregaard R.O. Jr., Gascon C., Lovejoy T.E., Mesquita R.C.G. (Eds.), Lessons from Amazonia: the ecology and conservation of a fragmented forest, Yale Univ. Press, New Haven, pp. 208-218.

Ortiz-Mora R.A., van Veen J.W. (1995) Influence of altitude on the distribution of stingless bees (Hymenoptera Apidae: Meliponinae), Apiacta, 101-105.

Portugal-Araujo V. (1957) Obtenção e Transferência de colônias de abelhas sem ferrão, Gaz. Agric. Angola 1, 469-473.

Posey D.A., Camargo J.M.F. (1985) Additional notes on the classification and knowledge of stingless bees (Meliponinae, Apidae, Hym.) by the Kayapo Indians of Gorotide (Para, Brazil), Ann. Carnegie Mus. 54, 247-274.

Ramírez A.F., Ortiz M.R. (1995) Crianza de las abejas sin aguijón, Costa Rica.

Rasmussen C., Castillo O.S. (2003) Estudio preliminar de la meliponicultura o apicultura silvestre en el Peru (Hymenoptera: Apidae, Meliponini), Rev. Peruvian Entomol. 43, 159-164.

Ratnieks F., Hart A. (2001) Melipona beecheii beekeeping in Yucatán, Bee Improvement 9, 8-11.

Ribeiro M.F., Wenseleers T., Santos-Filho P., Alves D.A. (2006) Miniature queens in stingless bees: basic facts and evolutionary hypotheses, Apidologie 37, 191-206.

Rosso J.M., Imperatriz-Fonseca V.L., CortopassiLaurino M. (2001) Meliponicultura en Brasil I: Situacion em 2001 y Perspectivas, in Memórias del II Seminário Mexicano sobre Abejas sin Aguijón, Mérida, México, pp. 28-35.

Roubik D.W. (1983) Nest and colony characteristics of stingless bees from Panama (Hymenoptera: Apidae), J. Kans. Entomol. Soc. 56, 327-355.

Roubik D.W. (1996) Wild bees of Brunei Darussalam in: Edwards D.S., Booth W.E., Choy S.C. (Eds.), Tropical Rain Forest Research: Current Issues, Monographiae Biologicae, Vol. 74, Kluwer, pp. 59-66.

Roubik D.W. (2000) Pollination system stability in tropical America, Conserv. Biol. 14, 1234-1235.

Roubik D.W. (2006) Stingless bee nesting biology, Apidologie 37, 124-143.

Samejima H., Marzuki M., Nagamitsu T., Nakasizuka T. (2004) The effects of human disturbance on a 
stingless bee community in a tropical rainforest, Biol. Conserv. 120, 577-587.

Santana W.C., Freitas G.S., Akatsu I.P., Soares A.E.E. (2004) Abelha iratim (Lestrimelitta limao Smith: Apidae, Meliponinae) realmente é danosa às populações de abelhas? Necessita ser eliminada? Mensagem Doce 78, 2-12 [online] http:// apacame.org.br / mensagemdoce / 78 / artigo.htm (accessed on 17 February 2006).

Santos-Filho P.S, Alves D.A., Eterovic A., ImperatrizFonseca V.L., Kleinert A.M.P. (2006) Numerical investment in sex and caste by stingless bees (Apidae: Meliponini): a comparative analysis, Apidologie 37, 207-221.

Shevelev I.F. (2003) El maravilloso "Tapezuá” Scaptotrigona bipunctata, Koéyu Ed. Asunción, Paraguay.

Silva V.C.E. (2005) Caracterização e pasteurização de méis de abelhas Apis mellifera (africanizada) e Melipona fasciculata (uruçu-cinzenta), Dissertação, Universidade Federal do Pará, 66 p.

Silva G.F., Venturieri G.C., Silva E.S.A. (2004) Meliponiculture as a sustainable development alternative: financial management within family groups in northeast Amazon, Brazil, in: FAO report, Economic value of pollinators and pollination.

Slaa E.J., Sanchez L.A., Sandí M., Salazar W. (2000) A scientific note on the use of stingless bees for commercial pollination in enclosures, Apidologie 31, 141-142.

Slaa E.J., Sánchez Chaves L.A., Malagodi-Braga K., Hofstede F.E. (2006) Stingless bees in applied pollination: practice and perspectives, Apidologie 37, 293-315.

Sommeijer M.J. (1996) A regional program for training and research on tropical beekeeping and tropical bees in Costa Rica, Bee World 77, 3-7.

Stierlin E., Szabo H. (2004) Manual de manejo de abejas nativas, suro y obobosi Scaptotrigona spp, Aguarague, Santa Cruz de la Sierra, Bolivia.

Szabo H., Stierlin E. (2006) El conocimiento sobre manejo de abejas nativas entre los Ayoreos de la Tco Guaye, Aguarague, Santa Cruz de la Sierra, Bolivia, in press.

van Veen J.W., Bootsma M.C., Arce H., Hallim M.K.I., Sommeijer M.J. (1990) Biological limiting factors for the beekeeping with stingless bees in the Caribbean and Central America, Social insects and Environment, 11th Int. Congr. IUSSI. Bangalore, India. Oxford and IBH Publishing Co, pp. 772-773.

van Veen J.W., Arce A.H.G., Sommeijer M.J. (1993) Manejo racional de la abeja sin aguijón Melipona beecheii (Apidae:Meliponinae), I. Como transferir la colonia de un tronco hueco a una caja, in: Perspectivas para una Apicultura Sostenible, van Veen J.W., Arce H.G. (Eds.), Conf. II Congr. Nac. Apicultura MAG, pp. 41-45.

van Veen J.W., Arce A.H.G., Sommeijer M.J. (2004) Production of queens and drones in Melipona beecheii (Meliponini) in relation to colony development and resource availability, Proc. Neth. Entomol. Soc. 15, 35-39.

Velthuis H.H.W., van Doorn A. (2004) The breeding, conservation and economic value of bumblebees, in: Freitas B.M., Pereira J.O.P. (Eds.), Solitary bees: conservation, rearing and management of pollination, Ed. Universitaria, Fortaleza, Brasil, pp. 135-149.

Venturieri G.C., Imperatriz-Fonseca V.L. (2000) Scaptotrigona nigrohirta e Melipona melanoventer (Apidae, Meliponinae): Espécies amazônicas com potencialidade para a meliponicultura, Anais do 4. Encontro sobre Abelhas, Ribeirão Preto, São Paulo, 356.

Venturieri G.C., Raiol V.F.O., Pereira C.A.B. (2003) Avaliação da introdução de Melipona fasciculata (Apidae: Meliponina) entre os agricultores familiares de Bragança, Belém, Biota Neotropica, 3, [online] http://www.biotaneotropica.cria.org.br/ v3n2/ (accessed on 17 February 2006).

Venturieri G.V., Rodrigues S.T., Pereira C.A.B.. (2005) As abelhas e as flores do açaizeiro (Euterpe oleracea Mart.,Arecaceae), Mensagem Doce 80, 32-33.

Villanueva G.R., Roubik D.W., Colli-Ucán W. (2005a) Extinction of Melipona beecheii and traditional beekeeping in the Yucatán Peninsula, Bee World $86,35-41$.

Villanueva G.R., Buchmann S., Donovan A.J., Roubik D.W. (2005b) Crianza y manejo de la abeja Xunan cab en la Península de Yucatán, ECOSURUniversity of Arizona, USA.

Villas-Bôas J.K., Malaspina O. (2005) Parâmetros físico-químicos propostos para o controle de qualidade do mel de abelhas indígenas sem ferrão no Brasil, Mensagem Doce 82, 6-16 [online] http:// apacame.org.br / mensagemdoce / 82/ artigo2.htm (accessed on 17 February 2006).

Vit P., Rios S.M., Novoa M., Füller R., Camargo J.M. (1994) Antibacterial activity and mineral content of Venezuelan stingless bee honeys, in IBRA Proc. 5th Int. Conf. on Apiculture in Tropical Climates, pp. 254-258.

Vit P., Medina M., Enriquez M.E. (2004) Quality Standards for Medicinal uses of Meliponinae honey in Guatemala, México and Venezuela, Bee World 85, 2-5.

Wille A. (1961) Las abejas jicotes de Costa Rica, Rev. Biol Trop. 24, 123-147. 